\author{
Matea Zajc Petranović, ${ }^{1}$ Julija Erhardt, ${ }^{2}$ \\ Matija Mato Škerbić, ${ }^{3}$ Nataša Jermen, ${ }^{4}$ Petra Korać ${ }^{5}$ \\ ${ }^{1}$ Institute for Anthropological Research, Gajeva 32, HR-10000 Zagreb \\ ${ }^{2}$ University of Zagreb, Faculty of Science, Rooseveltov trg 6, HR-10000 Zagreb \\ ${ }^{3}$ University of Zagreb, Faculty of Croatian Studies, Borongajska cesta 83d, HR-10000 Zagreb \\ ${ }^{4}$ The Miroslav Krleža Institute of Lexicography, Frankopanska 26, HR-10000 Zagreb \\ ${ }^{5}$ University of Zagreb, Faculty of Science, Horvatovac 102a, HR-10000 Zagreb \\ ${ }^{1}$ matea@inantro.hr, ${ }^{2}$ julija.erhardt@biol.pmf.hr, \\ ${ }^{3}$ mskerbic@hrstud.hr, ${ }^{4}$ natasa.jermen@1zmk.hr, ${ }^{5}$ petra.korac@biol.pmf.hr
}

\title{
Genome Editing and Selection Based on Genes Associated with Sports Athletic Performance - Some Bio-Ethical Issues
}

\begin{abstract}
In 2003 the final results of the Human Genome Project revealed the details of our genome: a set of information about how human beings look, how we act, feel, think and develop. Soon after, other global collaborations such as the HapMap project and 1000 Genomes Project were conducted. Although the main focus was to investigate the variability in human populations and the possible connections of certain variations to different conditions and diseases, these projects also had a great impact on the understanding of the genetic influence on sports performance. In parallel, improved methods for gene analysis and gene editing were developed. Based on those methods, it became possible to detect candidate genes responsible for different performance phenotypes and develop protocols similar to gene therapies for performance enhancement in athletes. This review covers developments in genetics, the overview of candidate genes associated with athletic performance, and ethical dilemmas related to the modification of genome for sport performance enhancement.
\end{abstract}

\section{Keywords}

enhancement of sport performance, sequencing, genome editing, candidate genes, ethical dilemmas

\section{Introduction}

As science and technology develop, our attitudes and actions should take into account all the new findings and possibilities. One field particularly susceptible to such advancements is that of sports, with a plethora of victories and broken records closely linked to scientific and technological advancements (Schneider \& Rupert, 2006; Camporesi \& McNamee, 2018). Athletes, their coaches and companies that cover professional sports market today far too often use unauthorised, forbidden, harmful or at least unsecure practices in their quest for "gold" and fame. Supported by their whole teams, athletes and coaches are losing perspective of what could be harmful. With the ability to select or change the genome (biological information that defines every organism) of an athlete, sports could attain a new powerful tool that might enable results unattainable for current athletes. Genetic engineering could be used in 
procedures for enhancing the performance, which is collectively called gene doping.

The discovery of genes shown to confer athletic ability and the idea of modification of "sports performance genes" were for the first published in 1998 in the New Scientist magazine by Montgomery et al. (Montgomery et al., 2018:221-222). Following further advances in the field of genetics and genetic engineering, in 2003 the International Olympic Committee (IOC) put a ban on gene doping and in the year that followed, the World Anti-Doping Agency (WADA) added gene doping as a prohibited procedure (World Anti-Doping Agency, 2017).

In its 2018 Prohibited List, WADA defines gene doping as "all possibilities of gene or cellular transfer aimed at enhancing athletic performance", and include the non-therapeutic use of genes, genetic elements or cells that have the potential to enhance athletic performance. It encompasses both gene and cellular therapy (Camporesi \& McNamee, 2013). WADA clearly states that the transfer of any nucleic acid or nucleic acid analogues, as well as the use of any normal or genetically modified cell in prohibited (World Anti-Doping Agency, 2017).

However, practices in sports proved these cautions premature. It is not known whether gene doping has been used to enhance athletic performance, although some attempts have been identified. For example, there was a case of a German coach who attempted to obtain a gene transfer vector that induces an expression of the erythropoietin gene, Repoxygen, or the case of a Chinese genetic laboratory, which was offering gene-based manipulations before the Olympic games in Beijing in 2008, both of which were unsuccessful (Friedmann, Rabin \& Frankel, 2010:647-648).

The use of gene doping will inevitably follow advancements in the gene therapy field. Although the field of genetic therapy has been intensively researched and consequently followed by numerous clinical trials, only a couple of gene therapies have been approved by the regulatory authorities. ${ }^{1}$ Despite high effectiveness in approved cases, gene therapy is very risky with several unfortunate cases of side effects such as treatment-induced secondary diseases, or even death (Friedmann, Rabin \& Frankel, 2010:647-648). Although there is evidence for risk, it is likely that some of the athletes will not wait for for clinically approved, safe procedures, before trying gene doping treatments.

The production of gene doping material can be achieved using simple and affordable technology, but designing treatment protocols for enhancement of athletic performances, that are both safe and effective, should be done according to the ethical standards of clinical work. Reasons for the relative lack of success in gene therapy and gene doping, excluding technical hurdles, include physiological problems (Friedmann, 2010:20-22). Gene doping changes are likely to induce broad genomic, proteomic and metabolomic changes in the body. All these changes manifest in the overall physiology, individual functioning and behaviour of a person. The individual's physiological state is described with the term "physiome" in extension to the widely used terminology of genome and proteome. In an ideal case, changes that the insertion of a new gene could induce on the level of the whole organism would be firstly checked using a computer model allowing early estimation of possible consequences in silico. Great advances towards creating such models have been made in the Physiome Project, which started in 1993 in Australia to provide a quantitative description of physiological dynamics and functional behaviour of the intact organism. The Physiome Project became a major focus of the International Union of Physiological Sciences in 2001. From then on, several 
projects aimed to create a model that will connect genes, proteins and their networks with the overall physiology of the organism (Bassingthwaighte, 2000:1043-1058). However, designing a model that could serve for better understanding of physiological implications caused by the inserted gene is still not possible.

Several physiological traits have been identified as candidates that could contribute to athletic performance, and that could be changed using genetic engineering. General doping strategies differ depending on the type of sport and on whether endurance, speed or muscle strength are key factors for the particular sport. The main targets of doping are improvements in tissue efficiency and metabolic activity, achieved by changes in oxygen delivery, glucose metabolism, muscle growth, endurance and pain prevention or a combination of these traits. Such physiological functions are regulated by hundreds of genes and their interplay, which makes the specific gene-choosing process quite difficult. Still, in current medical practices and literature, several genes have been identified and suggested as possible targets. The most often mentioned proteins are erythropoietin (EPO), insulin-like growth factor (IGF), growth hormone $(\mathrm{GH})$, myostatin, vascular endothelial growth factor (VEGF), fibroblast growth factor (FGF), endorphin and enkephalin, $\alpha$-actinin-3 (ACTN3), peroxisome proliferator-activated receptor-delta (PPAR $\delta$ ) and cytosolic phosphoenolpyruvate carboxykinase (PEPCK-C) (Gould, 2012:292-298, Fischetto \& Bermon, 2013; van der Gronde et al., 2013:670-678).

This review aims to cover recent developments in the field of genetics, provide a basic overview of candidate genes that are associated with athletic performance and discuss the ethical consequences of these practices.

\section{Short history of genetics and its key projects}

The "hereditary particles", genes were discovered in 1866 by Gregor Mendel, and DNA was isolated for the first time by Johannes Friedrich Miescher three years later. However, it took more than 70 years to connect these two discoveries and show that genes are made of DNA (Brown, 2006). With the concept of "hereditary particles" being DNA fragments, the only question left was: how does DNA look like? In 1953 James D. Watson and Francis H. C. Crick, based on the work of Rosalind E. Franklin, made a model of DNA structure (Watson \& Crick, 1953:123-131). This led to research that considered inheritance in humans, variations of traits between people and connection of different genes with different traits. In parallel with the discoveries about gene association with different states in humans, technological development allowed accurate gene analysis. In 1978 two methods for DNA sequencing were published (Sange, Nicklen \& Coulson, 1977:5463-5467; Maxam \& Gilbert, 1977:560-564). Since then, it is possible to analyse genes responsible for different human traits, as well as differences between different genetic variations for the same trait.

One of these two methods, today known as Sanger sequencing, was used as a basic tool for The Human Genome Project (HGP). The HGP started in 1990, intending to identify all human genes, find their location and elucidate the sequence of their DNA. A draft version of the human genome $(90 \%$ of its se-

1

Available at: https://www.fda.gov/vaccinesblood-biologics/cellular-gene-therapy-prod-

ucts/approved-cellular-and-gene-therapyproducts (accessed on 21 October 2018). 
quence) was published in 2001, and in 2003 the complete human genome sequence was published. It contained information on how many genes there are in the human genome (around 20,500), and on their sequence and location. All data instantly became publicly available (Brown, 2006). During 13 years of the HGP research, many new methods for gene analysis were developed, and at the end of the study, sequencing technology was much more available because of hugely decreased cost for such tests and widespread availability of needed technology. Other global collaborations followed: the HapMap project, and the 1000 Genomes Project, which focused on the variability in human populations (International HapMap Consortium, 2003:789-796; 1000 Genomes Project). They gathered information about the diversity of genetic variations in different populations around the world and associated certain genes with specific characteristics, even diseases.

In short, the HGP was conducted using DNA samples from only four people, and it generated a map of human genes in 2003. HapMap project started in 2002 , ended in 2005, and the first phase of the project analysed DNA samples of 269 individuals from four populations. The 1000 Genomes project began in 2008 , ended in 2015, and analysed 2504 samples from 26 populations. All three projects published their results and made all details publicly available as soon as they elucidated any information. ${ }^{2}$ In this way, knowledge about how many genes we have, their variations between populations, where they are located, and how they look like, became information available to all.

\section{Detection of athletic performance-associated genes and the methods of genetic manipulation}

Due to the increased number of findings indicating the association of different alleles with better athletic performance and development of gene-editing tools, it became possible to change one person's genes to enable their better performance in sport.

There are two approaches for the identification of genes associated with sports performance. Association studies often use one of the next-generation sequencing methods to sequence genes in a specific group of athletes and compare this data to the sequences of the same genes in the group of the nonathletes. After the biostatistical comparison of these data, the variants found more frequently in the athletes are said to be associated with the specific, investigated sport performance. The other approach connects genetic variations found in the well-known athletes with specific physiological traits and in this way, link them to certain athletic performance. Both ways use sequencing methods to detect genes and alleles associated with sports performance. Due to the decreased cost of these methods, it became possible to develop a use-athome test that can identify different levels of sport ability. Several companies provide services and produce use-at-home kits for analysing a panel of genes associated with sport performance. Anyone can order these tests, but whether they are reliable and could precisely and unmistakably assess one's ability in sport remains questionable (Camporesi \& McNamee, 2013; Collier, 2012: E43-E44).

An important consequence of gene variants associated with sport performance is not only the genetic screening between the athletes to identify those among them who already have specific gene variants, but also the ability to deliberately change variations in the cells of a person that wishes to be better in sports achievements. 
Today there are three gene-editing tools with different levels of specificity and different approaches for eukaryotic cells genome editing: (1) zinc finger nucleases (ZFNs), (2) transcription activator-like effector nucleases (TALENs), and (3) clustered regularly interspaced short palindromic repeats/ CRISPR-associated protein 9 (CRISPR/Cas9) methods (Y.-G. Kim, Cha \& Chandrasegaran, 1996:1156-1160; Christian et al., 2010:757-761, Cong et al., 2013:819-823; Mali et al., 2013:823-826; Wang et al., 2014:80-84; Cho et al., 2013:230-232; Jinek et al., 2013:e00471). ZFNs are based on the recognition of the DNA by zinc-finger proteins, and they ensure the specificity of the DNA sequence that will be changed. This method is expensive and takes a lot of time. The method that uses TALENs is similar: it is also based on the proteins for the specific recognition of DNA sequence that will be edited, but instead of zinc-finger proteins, transcription activator-like effectors are used. It is more precise than the ZFNs method, has a higher success rate, but is also quite expensive and takes a lot of time. The CRISPR/Cas9 method uses RNA molecule for specific recognition of DNA. It has a high success rate, minimal cost and minimal required time for execution. Using the CRISPR/Cas9 method, it is possible to change genes in many different ways: they can be turned off by making an incision in the middle of the allele, a specific nucleotide or even a short DNA sequence can be deleted from the allele, a nucleotide or a short sequence can be inserted, or they can be changed with different nucleotides or short sequences.

Moreover, the genome editing tools are being adjusted, and the epigenome editing tools are produced. Such methods can change not only the gene sequence itself but the first line of gene expression regulation as well. They can activate the inactive genes or inactivate the genes that are active in specific cells. Thus far, these technologies were used in studies aiming to treat different genetic diseases such as Barth syndrome, Duchenne muscular dystrophy, hemophilia, $\beta$-thalassemia, chronic inflammatory lung diseases, and even Huntington's disease (Mussolino et al., 2017:1105-1115; Thakore et al., 2016:127-137; Song et al., 2017:L334-L347). In the field of biomedicine, it works in a way that after the discovery of a gene aberration and its association with the disease, the CRISPR/Cas9 method could be used to reverse that aberration and treat specific disease by treating its cause. Such usage of the described methods represents one very precise form of gene therapy. To enhance sport performances, the same concept can be used. The first step would be the usage of sequencing methods for the identification of genetic variation associated with better athletic performance. Next step would be the usage of the CRISPR/Cas9 method for changing the specific gene sequence and producing desirable gene variant instead of the one already present in athletes.

\section{Genes associated with athletic performance}

As already mentioned, different genes carry information for different traits, and each gene can have two or more variations in a population (alleles). Gene relevant for the certain process in the human body allows this process to be functional in all humans but based on the individual specificity determined by the alleles, specific processes in different people may vary. For example,

Available at: https://www.ncbi.nlm.nih.gov/ genome/guide/human/, ftp://ftp.ncbi.nlm.nih. gov/hapmap/, and https://www.ncbi.nlm.nih.

gov/variation/tools/1000genomes/ (accessed on 21 October 2018). 
painkillers can be processed differently in different people. For the same type and intensity of the headache some people need smaller painkiller dosages, some need the same painkiller more frequently, some less frequently, while some might not even feel the effect of the pill. The reason for this is that the chemical in a painkiller is processed in cells of all people by the same mechanism based on the same genes, but variations of this mechanism are based on the function of different alleles. All processes in the human body, including the processes that enable sport performance, have the same basis: mechanisms that vary due to alleles of a certain gene.

Changes in the DNA sequence that permanently alter gene activity and protein function are called mutations. Mutations can be harmful or beneficial, and while the harmful ones are usually removed from the population, the advantageous ones are more likely to be passed to the next generation - this process is called a natural selection (Reece et al., 2013). Mutations that resulted in traits which increased the ability to survive (fitness) were under positive selection, and among especially favoured were ones responsible for the adaptation to the environment - a latitude and a climate in particular. For that reason, persons originating from diverse geographical regions differ anthropometrically and in body composition, which may predispose their athletic ability in a particular sport. In addition to the appropriate physique, physiological characteristics like better muscle performance, higher endurance, cardiac output or the ability to use oxygen more efficiently would also contribute to personal differences. It is estimated that genetic factors highly influence $20 \%$ to $80 \%$ of a wide variety of these and similar traits relevant to physical performance (de Moor et al., 2007:812-820; MacArthur \& North, 2007:30-34; Bouchard, 2012:347-352; dos Santos et al., 2016:600-612). Possible influence of dozens of genes and hundreds of their genetic variants on the athletic performance has been investigated over the last decades (van der Gronde et al., 2013:670-678; Eynon et al., 2013:803-817), but in this paper we will focus only on those that are thus far best analysed.

Among the genes associated with the physical performance, maybe the most widely investigated are $\alpha$-actinin-3 gene (ACTN3) and angiotensin-converting enzyme gene $(A C E)$, that influence the fibre type of muscles. ACTN3 gene product, the $\alpha$-actinin-3 protein, predominantly found in type II skeletal muscle fibres, is involved in stabilisation of the contractile apparatus and important for generating rapid forceful contractions in activities that require power or strength like sprinting and weightlifting (MacArthur \& North, 2007:30-34; Mills et al., 2001:1335-1346; Yang, Garton \& North, 2009:88-101). A common polymorphism (C>T, rs1815739) found in the coding part of the ACTN3 gene called exon 16, results with a premature stop codon (X) at amino-acid 577 of the protein (North et al., 1999:353-354). When it is inherited from both parents, this polymorphism influences an individual's athletic performance. In comparison with the general population, the under-representation of ACTN3 577XX genotype was detected in many studies of sprint and power athletes, regardless of the sex and the ethnicity (reviewed in Eynon et al., 2013:803-817) and confirmed in the meta-analysis in European sprint/power athletes (Alfred et al., 2011:1008-1018). This is the only gene that shows a genotype and performance association across multiple groups of elite power athletes and this association is strongly supported by mechanistic data from an Actn3 knockout mouse model (Berman \& North, 2010:250-259). It is estimated that there are 1.5 billion people worldwide who are deficient in this skeletal muscle protein (Amorim et al., 2015:e0115449). Still, evidence for positive selection of ACTN3 gene (MacArthur et al., 2007:1261-1265) might 
be due to its capability to impact several other traits, including exercise recovery, injury risk, and training adaptation (Pickering \& Kiely, 2018).

The presence (insertion, I allele) or the absence (deletion, D allele) of 287 base pairs from the non-coding part of the $A C E$ gene called intron 16 was the first polymorphism found to be associated with the physical performance. $A C E$ gene provides instructions for the synthesis of angiotensin-converting enzyme (ACE), which converts angiotensin I to angiotensin II, a vasoconstrictor which helps in regulating blood pressure. Individuals with I allele have lower ACE protein plasma and tissue levels (Rigat et al., 1990:13431346), while individuals with $A C E \mathrm{D}$ allele have elevated levels of ACE protein and elevated blood pressure, which puts them under a higher risk for the development of cardiovascular diseases (Zhang et al., 2012:e46495). In comparison with Caucasian athletes who carry D allele, those with I allele were found to have better energy balance in long-term exercise and increased endurance (Santiago et al., 2010:e188-e194; Holdys et al., 2011:223-231; Ma et al., 2013:e54685; Gineviciene et al., 2016:199-206), what was particularly evident in males (Min et al., 2009:926-932). The D allele carriers, although initially showed better sprint-power results (Cerit et al., 2006:461-465), in the latter study showed conflicting results (Amir et al., 2007; 92: 881-886). Still, D allele seems to have been positively selected in modern humans due to better regulation of water and sodium balance in the ancestral environment (before the out-of-Africa) (Roth, 2012:247-255).

Frequencies of minor alleles in the mentioned polymorphic loci, $A C E$ ID and $A C T N 3$ R577X, normally vary between different populations, but there are also rare, private mutations that may affect someone's athletic ability. One of the most famous examples is a case of Eero Mäntyranta, a participant in 1964 Winter Olympic Games in Innsbruck, who won two gold medals in country skiing as well as a silver medal in the $4 \times 10$ kilometres $(\mathrm{km})$ relay. And not only that he won both country skiing races but was 40.7 seconds faster in the $15 \mathrm{~km}$ race and 71.6 seconds in the $30 \mathrm{~km}$ race than both races silver medal winner, Norwegian Harald Grønningen. Mäntyranta also successfully competed in previous, the 1960 Olympic Games, where he won the first place in relay, as well as in the following, the 1968 Olympic Games (won the second place in the $15 \mathrm{~km}$ race and two bronze medals in the $30 \mathrm{~km}$ race and relay). These results made him one of the most successful Finnish skiers, but also led to rumours that he was blood doping; since he started competing professionally, as a teenager, it was known that Eero Mäntyranta had high haemoglobin and far more than usual amount of erythrocytes, red blood cells (his hematocrit - a proportion of red blood cells in the blood, was 0.60-0.65, while normal male hematocrit ranges 0.40-0.54) (de la Chapelle, Träskelin \& Juvonen, 1993:4495-4499). At that time there were no drug restriction rules in the Olympics, so he was not penalised, but for the following 29 years Mäntyranta's success, despite his denial, was considered to be a result of cheating either by taking blood transfusions or drugs to raise haemoglobin. High haemoglobin levels contribute to better oxygen supply of muscle cells preventing their tiredness, but the excess number of red blood cells thickens blood slowing its flow and may cause blood clots, which elevates the risk for the development of cardiovascular diseases (heart attack or stroke) (Lee et al., 2018: e007723). In 1991 Finnish scientists described genetics of autosomal dominant erythrocytosis in Mäntyranta's family: 29 out of the 97 analysed family members showed high haemoglobin blood levels and the experiments on their cell cultures in vitro indicated that this familial erythrocytosis was caused by 
hypersensitivity of erythroid cell colonies to the glycoprotein erythropoietin (Epo) (Juvonen et al.,1991:3066-3069). The same authors soon reported finding G6002A mutation in exon 8 of the erythropoietin receptor gene (EPOR) in the same family, which resulted in a premature stop codon (W439X) and predicted to truncate the receptor by 70 amino acids shorter (de la Chapelle, Träskelin \& Juvonen, 1993:4495-4499). EPO protein, which is produced in response to hypoxia in blood, binds to EpoR receptor and initiates a cascade of reactions leading to the stimulation of proliferation and differentiation of erythrocytes (Jelkmann, 2004:649-659). In Mäntyranta's family, a mutation in the EPOR gene made it seem like EPO was permanently bound to EpoR protein which led to the overproduction of red blood cells. EPOR autosomal dominant mutations causing erythrocytosis are rare, but some genetic variants in hypoxia-related pathways (more than 200 genes are involved in these pathways - Simonson et al., 2010:72-75) are proved to be positively selected in high-altitude populations, like Tibetans who inhabit $>3,000$ meters high plateau, enabling them to biologically adapt to the high-altitude hypoxia (Peng et al., 2011:1075-1081).

Besides these studies, which aimed to detect and explain why some persons are predisposed to be better in sports, other studies investigated possible associations between genes and some of the most common injuries and health problems in professional athletes. For instance, genome-wide association study (GWAS) analysis conducted in almost 100,000 people (1,700 of whom were ankle injury cases) resulted in detection of two loci associated with ankle injury phenotypes: one insertion/deletion close to a collagen gene, COL18A1, and rs13286037 polymorphism that lies within an intron of the transcription factor gene NFIB (S. K. Kim et al., 2017:e0185355). Furthermore, high-intense physical activity may result in cardiac changes: the cyclists with left ventricular hypertrophy had differently regulated MYL9 and IL6ST gene expression compared to athletes with normal heart dimensions (Janikowska et al., 2017:999-1004).

In aetiology of concussion, which happens very frequently in contact sports, besides already known risk factors like age, gender, number of games/matches played, and previous history, the genetic role was also emphasised; rugby players with $A P O E$ gene haplotype rs405509G-E3 had increased susceptibility to concussion history, while those with rs405509 TT genotype recovered from the concussion significantly faster than G-allele carriers (Abrahams et al., 2018:117-122). APOE protein is essential for the normal catabolism of triglyceride-rich lipoprotein constituents, and the $A P O E$ gene is also one of the pleiotropic genes associated with the strong genetic risk for Alzheimer's disease.

\section{Gene editing in adults and embryos}

With the development of gene-editing tools, two important aspects need to be addressed: (1) delivery methods to specific cells, and (2) editing of adult or embryo genome - the same tools can be used for editing embryonic as well as adult cells genome, the only difference is a consequence on the organism. If genome editing is used in embryonic cells, then the whole organism that will develop from that embryo will have the same, edited genes in all its cells. If this method would be used in preimplantation stages of in vitro fertility procedures, the selected embryos would carry high athletic performance potential and could develop into elite athletes. On the other hand, if the described 
methods would be used in adult individuals, genome editing tools would have to be delivered specifically to cells that express genes of interest, and in this way, it would be possible to improve the athletic performance of athletes already engaged in a specific sport. Delivery methods that are being developed and improved for gene therapy could also be used for gene doping.

\section{Ethical dilemmas of gene editing to enhance sports performance}

The possible use of gene doping in sports brings many ethical problems and dilemmas. It can lead us to rethink our understanding of what sport is, what is its meaning and purpose, as well as what kind of abilities and performances we would expect from future athletes. Many athletes are focused on their immediate sports achievements and often have a 'win at all costs attitude', discounting their future health for current athletic success (Friedmann, Rabin \& Frankel, 2010:647-648, 660). It seems that the personal health of an athlete is not always the priority of sports medicine either. Rather it is enabling athletes to compete and to return to the sports competition as fast as possible. Nevertheless, when it comes to highly sophisticated procedures like gene doping, it is unlikely that sports physicians could predict possible far-reaching outcomes. Although gene doping could be banned based on safety issues alone, there are several other ethical concerns.

In the philosophy of sport literature thus far, problems relating to human genes, advancements of genetic technologies and gene modification, have been thematised in many articles and books. From 2001 onwards, starting with Andy Miah's article "Genetic Technologies and Sport: The New Ethical Issue", genetics in sports has become one of the central issues considered and discussed by many authors, such as Claudio Tamburrini and Torbjörn Tännsjö (2005), Silvia Camporesi and Mike McNamee (2013, 2017, 2018), Angela J. Schneider (2006, 2009), Walter Miller Brown $(2009,2015)$ and Andy Miah (2001, 2004, 2007, 2016), among others. Theodore Friedmann stands out not only because of his contributions through papers and books $(2006,2010)$ but even more as a president of the American Society of Gene Therapy and Chair of WADA's Gene Doping Expert Group (Friedmann \& Schneider, 2006; Friedmann, Rabin \& Frankel, 2010:647-648).

All ethical issues regarding genes and genetics in the (bio)ethics of sport can be divided into two general groups. Firstly, there is a group of issues that can be seen from the viewpoints and arguments already developed in the history of sports-philosophy, such as fairness and gaining an unjust and unfair advantage, paternalistic decision-making, harming athlete's health, and coercion to make genome adjustments. Secondly, there is a group of issues that needs new considerations and solutions, where the history of the discipline doesn't help. The movie Gattaca (Niccol, 1997) is the perfect example of this, because it has anticipated, predicted and problematized several issues of the kind, also showing possible mistakes, problems, and limits.

\subsection{Gene doping issues in the doping-debate framework - the four principles}

The first group of ethical issues deals with human enhancements in terms of practising sports and in the context of the sports-philosophy and sports-bioethics literature. The most prominent sports-philosophers and sports-bio-ethi- 
cists like Warren Fraleigh, Walter Miller Brown, Angela Schneider, William Morgan, Robert Simon, Mike McNamee and Claudio Tamburrini, contributed to the 40-years ongoing doping debate (Škerbić, 2016:511-530). They have developed four principles that should be considered when discussing doping, which can and should be easily applied to the issues of the human gene(tic)s and sports: Harm-principle, Fairness-principle, Paternalistic-principle, and Coercion-principle (Škerbić, 2016; Schneider, 2016).

The question of harmfulness in considering genetic modifications and the betterment of present and future athletes is central. Scientists should first provide answers to the question: Are the procedures harmful to the athletes, and are they disrupting and damaging the athletes' health? However, as discussed in the introduction, due to the complexity of human physiology, establishing harmlessness is not straightforward. If harmlessness of specific gene doping procedure could be established, paternalism of the sports institutions and associations would be needless and futile. All the reasons for coercion towards non-genetically-improved athletes would be gone. On the other hand, if gene doping could be proven harmful, then the procedures for genetic improvement should be immediately dismissed. In that way, paternalistic bans should be considered and placed to prevent athletes from doing the modifications, and by this influence, others to do the same.

In terms of the paternalistic principle, the question is: Should every athlete of age have the freedom to decide whether they want to change their genes? How can we be sure that the athletes have made their decisions autonomously and without coercion? Another question is the role of the parents, educators, coaches or tutors and sports institutions (clubs and associations) in the decision-making process.

As far as fairness issues, several aspects need to be considered related to gene doping. The first is the gaining of an unfair advantage that needs to be assessed. The "old" fairness arguments are facing new circumstances and questions, such as:

"If an athlete has an unusually favorable phenotype (traits, obtained by gene doping) for a given sport, would this lead to their disqualification from competition based on their having an unfair advantage?" (Miah, 2016:2666-2676)

Here, WADA clearly prescribed in their policies that athletes with changes in their genome should be rejected from competitions. Furthermore, whenever we have an expensive treatment that could introduce an advantage for some, the problem of availability appears. Expensive treatments like gene doping that requires sophisticated laboratories and expert-doctors come with a cost that is affordable only to some. Is it fair to compare the results of teams/athletes who could afford the "optimization" of their bodies by gene doping with those who could not?

Interestingly, Andy Miah in the Encyclopedia of Global Bioethics (Miah, 2016:2666-2676; ten Have, 2016) expressed a strong pro enhancement attitude stating that "athletes must be allowed to discover new means of performance enhancement to take sport performances to new levels" (Miah, 2016:2675). Such a stand seems questionable and worrying in many ways, from medical and health, ethical and moral, to scientific and social.

\subsection{New ethical issues - new considerations and solutions}

Bringing new technologies, methods and procedures, and thus possibilities for enhancing athlete's performance abilities means also bringing new ethically problematic and questionable situations and issues. 
Firstly, the genetic modification of athletes would introduce a categorisation problem in sport. In the well-known case of Paralympic athlete Oscar Pistorius, who runs with his blades and has competed with able-bodied athletes, a general conclusion in the scientific debate that followed after he participated in standard competitions (such as the Olympic Games and World Championship) was that due to the nature of his prosthetics he was doing an "other type of locomotion" we can call "blading", while all the other (able-bodied) athletes were doing the "type of locomotion" - running (Camporesi, 2015:8197). Genetically changed athletes would introduce a need for new categories in sport based on the biology/physiology of the athlete, which might be very difficult to categorise. The solution could be the division of one sport and/or sports-discipline (like in gymnastics, athletics, swimming, etc.) in as many categories and sub-categories as differently genetically modified competitors require. In such a case, each sport should have different (sub-) categories depending on the enhancement made, either physical or psychological, with sub-disciplines containing modified intelligence, endurance, strength, resilience, mental toughness, or a combination of modifications. Here, practice and solutions developed for the Paralympic ${ }^{3}$ and Gay-games ${ }^{4}$ can be of crucial help - especially the divisions of sports competition to many specific disciplines and sub-disciplines according to athletes physical condition (of the disabled athletes in Paralympics) and/or stage of body changes (for instance, of a person going through a sex change in the Gay-games).

Other than changing somatic cells, changes in the genome that might create superb athletes could be introduced into reproductive cells. In that case, changes are introduced into the genome that will be inherited further and transferred to future generations. Whether the goal is the creation of homo athleticus or the reproductive cell lines are changed for some other reasons, we would be changing the evolution of the human specie in the most direct way. This practice, in popular culture often discussed under the topic of "designer babies" ("designer athletes"), is loaded with ethical dilemmas. Probably the most significant dilemma is the possible desensitising of the public towards the selection of more or less desirable people that can potentially lead to eugenic practices and thus needs to be treated with the utmost of care. These problems are comprehensively argued in several excellent reviews and books, and are not going to be further discussed here (Ball, 2017; Green, 2007; Sandel, 2015:93-105).

Furthermore, continuous enhancements (initially pharmacological, and now genetic) might be a road at the end of which awaits an athlete that isn't just homo sapiens any more, but rather homo athleticus? Question raises will sport become just another special branch of industry where the best molecular biologists and bio-informaticists will become the key persons in creating a new type of athlete? On the other hand, the question is, what will happen with natural athletes and their natural talent?

On a less futuristic level, an additional area of concern is the privacy of genetic information, whose security is part of broader policies and needs to be protected from breach and violations. In the case of an elite athlete, the question arises whether their genome can still be private. Can the sports medical teams evaluate and manipulate it to achieve a good competitive outcome for the athlete and/or team that they are a part of? It seems that a new protocol or

3

Available at: https://www.paralympic.org/classification (accessed on 21 October 212018 ).
4

Available at: https://www.paris2018.com/sportslist/ (accessed on 21 October 21 2018). 
privacy agreement should be developed for such a specific case or a specific area of (genetic) medicine and sport.

Genetic testing can say a lot about the potential medical problems of athletes and the possible predispositions to different health issues related to athletic performance. It furthermore reveals information about the athlete's family members. In the last edition of the Encyclopedia of Global Bioethics Miah emphasised that

“... established ethical codes of conduct are not adequately constructed to accommodate a number of novel scientific applications. It might also imply revising ethical protocols, such as the consent process, to account for the different ways in which people make sense of genetic information." (Miah, 2016:2671)

Therefore, the very institution and practice of informed consent should be changed and modified in a new way (Camporesi \& McNamee, 2018:61-67).

Finally, an issue of the usage of genetic screening to identify talented children with alleged athletic predisposition has several ethical and scientific concerns. The validity of data obtained with the genetic tests is questionable due to the complexity of factors that contribute to overall athletic performance and the fact that a certain gene often only contributes to a small proportion of the certain trait. For example, the acclaimed test for the ACTN3 variant accounts for only $2 \%$ of the total variance in muscle performance (Eynon et al., 2011:3063-3070). More importantly, sports in children have a complex role in developing motor skills that are closely related to the development of cognition, preserving physical health, learning social rules, etc. Limiting the possibility for children to engage in sports based on a possible suboptimal elite sport genetic profile would have several different negative consequences. Furthermore, these tests are impinging directly with children's autonomy rights, who are forced to learn about their "inferior athletic" potential, which might not be such after all. None of the parties involved (scientists, children, their parents and coaches) can fully understand the meaning and extent of these results and are therefore vulnerable to the aggressive marketing of companies that sells these tests, whose predictive ability is clearly overstated (Camporesi \& McNamee, 2013; Camporesi, 2015:81-97; Roth, 2012:247-255).

On the other hand, positive outcomes of such screening in preventing and detecting athlete's risk injuries (e.g. sudden cardiac arrest, concussion-related traumatic brain injuries, overexertion complications related to the sickle-cell anemia, Achilles tendinopathies, anterior crucial ligament ruptures) should not be discarded (Camporesi \& McNamee, 2013).

Genetics and genetic engineering have profoundly changed all areas of our lives, including sports. Justified concern about how this knowledge is going to be used is nicely expressed in Stephen Hawking's words:

"Our future is a race between the growing power of our technology and the wisdom with which we use it. Let's make sure that wisdom wins."5

\section{Future prospects}

The worry about gene doping at the beginning of the 21 st century, seem still to be premature. It is difficult to say how far away we are now from widespread gene therapy and/or gene doping. In any case, progress in gene therapy will precede successful gene doping in sports. With the CRISPR/Cas9 as a relatively new addition to the genetics toolbox, things might speed up a little (Neuberger \& Simon, 2017:91-106). However, we are still very far from be- 
ing able to study the human organism the way that would allow us to predict the consequences that changing of one gene might have for the whole system. Consequently, reckless individual attempts of gene doping would, most probably, be doomed to failure. On the other hand, we should be able to protect uninformed athletes from endangering their health because of false promises of "new scientific" enhancement methods.

However, while scientific research and technological development are advancing towards future in which the nontherapeutic use of gene engineering in sports will eventually become possible, it seems essential that bio-ethical discussion continues in trying to anticipate and build the solutions for such a future.

\section{Literature}

Abrahams, S. et al. (2018): "An association between polymorphisms within the APOE gene and concussion aetiology in rugby union players", Journal of Science and Medicine in Sport 21 (2018) 2, pp. 117-122. doi: https://doi.org/10.1016/j.jsams.2017.06.004.

Alfred, T. et al. (2011): “ACTN3 genotype, athletic status, and life course physical capability: Meta-analysis of the published literature and findings from nine studies", Human Mutation 32 (2011) 9, pp. 1008-1018. doi: https://doi.org/10.1002/humu.21526.

Amir, O. et al. (2007): "The $A C E$ deletion allele is associated with Israeli elite endurance athletes", Experimental Physiology 92 (2007) 5, pp. 881-886. doi: https://doi.org/10.1113/ expphysiol.2007.038711.

Amorim, C. E. G. et al. (2015): "Differing Evolutionary Histories of the ACTN3 R577X Polymorphism among the Major Human Geographic Groups", PLoS One 10 (2015) 2, pp. e0115449.

Ball, P. (2017): “Designer babies: an ethical horror waiting to happen?", The Guardian (8 January 2017). Available at: https://www.theguardian.com/science/2017/jan/08/designerbabies-ethical-horror-waiting-to-happen (accessed on 21 October 2018).

Bassingthwaighte, J. B. (2000): "Strategies for the Physiome Project", Annals of Biomedical Engineering 28 (2000) 8, pp. 1043-1058. doi: https://doi.org/10.1114/1.1313771.

Berman, Y; North, K. N. (2010): “A gene for speed: The emerging role of $\alpha$-actinin-3 in muscle metabolism", Physiology 25 (2010) 4, pp. 250-259. doi: https://doi.org/10.1152/ physiol.00008.2010.

Bouchard, C. (2012): "Genomic predictors of trainability", Experimental Physiology 97 (2012) 3, pp. 347-352. doi: https://doi.org/10.1113/expphysiol.2011.058735.

Miller Brown, W. (2015): "Genetics, Science Fiction and The Ethics of Athletic Enhancement", in: McNamee, M.; Morgan, W. J. (eds.), Routledge Handbook of the Philosophy of Sport, Routledge, London - New York 2015, pp. 351-367.

Miller Brown, W. (2009): "The Case for Perfection", Journal of the Philosophy of Sport 36 (2009) 2, pp. 127-139. doi: https://doi.org/10.1080/00948705.2009.9714752.

Brown, T. A. (2006): Genomes 3, Garland Science, New York 2006, p. 6.

Camporesi, S. (2015): "Bioethics and Sport", in: McNamee, M.; Morgan, W. J. (eds.), Routledge Handbook of the Philosophy of Sport, Routledge, London - New York 2015, pp. 81-97.

Camporesi, S.; McNamee, M. J. (2018): Bioethics, Genetics and Sport, Routledge, London.

Available at https://www.bioedge.org/bioethics/stephen-hawking-transhumanist/12863 (accessed on 21 October 2018). 
Camporesi, S.; McNamee, M. J. (2013): "Is There a Role for Genetic Testing in Sports?", eLS. doi: https://doi.org/10.1002/9780470015902.a0024203.

Camporesi, S.; McNamee, M. J. (2012): “Gene Transfer for Pain: A Tool to Cope with the Intractable or an Unethical Endurance-Enhancing Technology?", Genomics, society, and policy / ESRC Genomics Network 8 (2012) 1. doi: https://doi.org/10.1186/1746-5354-8-1-20.

Cerit, M. et al. (2006): "Relationship between $A C E$ genotype and short duration aerobic performance development", European Journal of Applied Physiology 98 (2006) 5, pp. 461-465. doi: https://doi.org/10.1007/s00421-006-0286-6.

Cho, S. W. et al. (2013): "Targeted genome engineering in human cells with the Cas9 RNA-guided endonuclease", Nature Biotechnology 31 (2013) 3, pp. 230-232. doi: https:// doi.org/10.1038/nbt.2507.

Christian, M. et al. (2010): "Targeting DNA double-strand breaks with TAL effector nucleases", Genetics 186 (2010) 2, pp. 757-761. doi: https://doi.org/10.1534/genetics.110.120717.

Collier, R. (2012): "Genetic tests for athletic ability: Science or snake oil?", Canadian Medical Association Journal 184 (2012) 1, pp. E43-E44. doi: https://doi.org/10.1503/ cmaj.109-4063.

Cong, L. et al. (2013): "Multiplex genome engineering using CRISPR/Cas systems", Science 339 (2013) 6121, pp. 819-823. doi: https://doi.org/10.1126/science.1231143.

de la Chapelle, A.; Träskelin, A.-L.; Juvonen, E. (1993): “Truncated erythropoietin receptor causes dominantly inherited benign human erythrocytosis", Proceedings of the National Academy of Sciences 90 (1993) 10, pp. 4495-4499. doi: https://doi.org/10.1073/ pnas.90.10.4495.

de Moor, M. H. M. et al. (2007): "Genome-wide linkage scan for athlete status in 700 British female DZ twin pairs", Twin Research and Human Genetics 10 (2007) 6, pp. 812-820. doi: https://doi.org/10.1375/twin.10.6.812.

Eynon, N. et al. (2013): "Genes for elite power and sprint performance: ACTN3 leads the way", Sports Medicine 43 (2013) 9, pp. 803-817. doi: https://doi.org/10.1007/s40279013-0059-4.

Eynon, N. et al. (2011): "Genes and elite athletes: a roadmap for future research", Journal of Physiology 589 (2011) 13, pp. 3063-3070. doi: https://doi.org/10.1113/jphysiol.2011.207035.

Fischetto, G.; Bermon, S. (2013): "From Gene Engineering to Gene Modulation and Manipulation: Can We Prevent or Detect Gene Doping in Sports?", Sports Medicine 43 (2013) 10, pp. 965-977. doi: https://doi.org/10.1007/s40279-013-0075-4.

Friedmann, T. (2010): "How Close Are We to Gene Doping?", Hastings Center Report 40 (2010) 2, pp. 20-22. doi: https://doi.org/10.1353/hcr.0.0246.

Friedmann, T.; Rabin, O.; Frankel, M. S. (2010): “Gene Doping and Sport”, Science 327 (2010) 5966, pp. 647-648. doi: https://doi.org/10.1126/science.1177801.

Gineviciene, V. et al. (2016): "Association analysis of ACE, ACTN3 and PPARGC1A gene polymorphisms in two cohorts of European strength and power athletes", Biology of Sport 33 (2016) 3, pp. 199-206. doi: https://doi.org/10.5604/20831862.1201051.

Gould, D. (2012): "Gene doping: gene delivery for Olympic victory", British Journal of Clinical Pharmacology 76 (2012) 2, pp. 292-298. doi: https://doi.org/10.1111/bcp.12010.

Green, R. M. (2007): Babies by Design: The Ethics of Genetic Choice, Yale University Press, New Haven - London 2007.

van der Gronde, T. et al. (2013): "Gene doping: an overview and current implications for athletes”, British Journal of Sports Medicine 47 (2013) 11, pp. 670-678. doi: https://doi. org/10.1136/bjsports-2012-091288.

ten Have, H. (ed. 2016), Encyclopedia of Global Bioethics, Springer. 
Holdys, J. et al. (2011): “ACE I/D gene polymorphism in athletes of various sports disciplines", Human Movement 12 (2011) 3, pp. 223-231. doi: https://doi.org/10.2478/v10038011-0022-X.

International HapMap Consortium (2003): “The International HapMap Project”, Nature 426 (2003) 6968, pp. 789-796. doi: https://doi.org/10.1038/nature02168.

Janikowska, G. et al. (2017): "Differences in echocardiography, blood pressure, stroke volume, maximal power and profile of genes related to cardiac hypertrophy in elite road cyclists", Advances in Clinical and Experimental Medicine 26 (2017) 6, pp. 999-1004. doi: https://doi.org/10.17219/acem/63031.

Jelkmann, W. (2004): "Molecular biology of erythropoietin", Internal Medicine 43 (2004) 8, pp. 649-659. doi: https://doi.org/10.2169/internalmedicine.43.649.

Jinek, M. et al. (2013): "RNA-programmed genome editing in human cells", eLife 2 (2013), p. e00471. doi: https://doi.org/10.7554/elife.00471.

Juvonen, E. et al. (1991): “Autosomal dominant erythrocytosis caused by increased sensitivity to erythropoietin”, Blood 78 (1991) 11, pp. 3066-3069.

Kim, S. K. et al. (2017): “Two Genetic Loci Associated with Ankle Injury”, PLoS One 12 (9/2017), p. e0185355. doi: https://doi.org/10.1371/journal.pone.0185355.

Kim, Y.-G.; Cha, J.; Chandrasegaran, S. (1996): "Hybrid restriction enzymes: zinc finger fusions to Fok I cleavage domain", Proceedings of the National Academy of Sciences 93 (1996) 3, pp. 1156-1160. doi: https://doi.org/10.1073/pnas.93.3.1156.

Lee, G. et al. (2018): "Association of Hemoglobin Concentration and Its Change with Cardiovascular and All-Cause Mortality", Journal of the American Heart Association 7 (2018) 3, p. e007723. doi: https://doi.org/10.1161/jaha.117.007723.

Li, X. et al. (2011): "Worldwide spatial genetic structure of angiotensin-converting enzyme gene: a new evolutionary ecological evidence for the thrifty genotype hypothesis", European Journal of Human Genetics 19 (2011) 0, pp. 1002-1008. doi: https://doi. org/10.1038/ejhg.2011.66

Ma, F. et al. (2013): "The Association of Sport Performance with ACE and ACTN3 genetic polymorphisms: a systematic review and meta-analysis", PLoS One 8 (2013) 1, p. e54685. doi: https://doi.org/10.1371/journal.pone.0054685.

MacArthur, D. G.; North, K. (2007): “ACTN3: a genetic influence on muscle function and athletic performance", Exercise and Sport Sciences Reviews 35 (2007) 1, pp. 30-34. doi: https://doi.org/10.1097/jes.0b013e31802d8874.

MacArthur, D. G. et al. (2007): "Loss of ACTN3 gene function alters mouse muscle metabolism and shows evidence of positive selection in humans", Nature Genetics 39 (2007) 10, pp. 1261-1265. doi: https://doi.org/10.1038/ng2122.

Mali, P. et al. (2013): "RNA-guided human genome engineering via Cas9”, Science 339 (2013) 6121, pp. 823-826. doi: https://doi.org/10.1126/science.1232033.

Maxam, A. M.; Gilbert, W. (1977): “A new method for sequencing DNA”, Proceedings of the National Academy of Sciences 74 (1977) 2, pp. 560-564. doi: https://doi.org/10.1073/ pnas.74.2.560.

Miah, A. (2016): "Sports", in: ten Have, H. (ed.), Encyclopedia of Global Bioethics, Springer, 2016, pp. 2666-2676.

Miah, A. (2007): "Genetics, bioethics and sport", Sport, Ethics and Philosophy 1 (2007) 2, pp. 146-158. doi: https://doi.org/10.1080/17511320701425181.

Miah, A. (2004): Genetically Modified Athletes: Biomedical Ethics, Gene Doping and Sport, Routledge, London, 2004.

Miah, A. (2001): "Genetic Technologies and Sport: The New Ethical Issue", Journal of the Philosophy of Sport 28 (2001) 1, pp. 32-52. doi: https://doi.org/10.1080/00948705.2 001.9714599 . 
Mills, M. et al. (2001): "Differential expression of the actin-binding proteins, alpha-actinin2 and -3 , in different species: implications for the evolution of functional redundancy", Human Molecular Genetics 10 (2001) 13, pp. 1335-1346. doi: https://doi.org/10.1093/ $\mathrm{hmg} / 10.13 .1335$.

Min, S.-K. et al. (2009: "Is there a gender difference between $A C E$ gene and race distance?", Applied Physiology, Nutrition, and Metabolism 34 (2009) 5, pp. 926-932. doi: https://doi.org/10.1139/h09-097.

Montgomery, H. E. et al. (2018): "Human gene for physical performance", Nature 393 (2018) 6682, pp. 221-222. doi: https://doi.org/10.1038/30374.

Mussolino, C. et al. (2017): "Genome and Epigenome Editing to Treat Disorders of the Hematopoietic System”, Human Gene Therapy 28 (2017) 11, pp. 1105-1115. doi: https:// doi.org/10.1089/hum.2017.149.

Neuberger, E. W. I.; Simon, P. (2017): "Gene and Cell Doping: The New Frontier - Beyond Myth or Reality" in: Rabin, O.; Pitsiladis, Y. (eds.): Acute Topics in Anti-Doping, Karger, Basel 2017, pp. 91-106.

North, K. N. et al. (1999): “A common nonsense mutation results in $\alpha$-actinin-3 deficiency in the general population", Nature Genetics 21 (1999) 4, pp. 353-354. doi: https://doi. org/10.1038/7675

Peng, Y. et al. (2011): "Genetic variations in Tibetan populations and high-altitude adaptation at the Himalayas", Molecular Biology and Evolution 28 (2011) 2, pp. 1075-1081. doi: https://doi.org/10.1093/molbev/msq290.

Pickering, C.; Kiely, J. (2018): “ACTN3, Morbidity, and Healthy Aging”, Frontiers in Genetics 9 (2018), p. 15. doi: https://doi.org/10.3389/fgene.2018.00015.

Reece, J. B. et al. (2013): Campbell Biology, Pearson, New York 2013.

Rigat, B. et al. (1990): “An insertion/deletion polymorphism in the angiotensin I-converting enzyme gene accounting for half the variance of serum enzyme levels", Journal of Clinical Investigation 86 (1990) 4, pp. 1343-1346. doi: https://doi.org/10.1172/jci114844.

Roth, S. M. (2012): "Critical Overview of Applications of Genetic Testing in Sport Talent Identification”, Recent Patents on DNA \& Gene Sequences 6 (2012) 3, pp. 247-255. doi: https://doi.org/10.2174/187221512802717402.

Sandel, M. J. (2012): “The Case Against Perfection: What's Wrong with Designer Children, Bionic Athletes, and Genetic Engineering?", in: Holland, S. (ed.), Arguing about Bioethics, Routledge, New York 2012, pp. 93-105.

Sanger, F.; Nicklen, S.; Coulson, A. R. (1977): "DNA sequencing with chain-terminating inhibitors", Proceedings of the National Academy of Sciences 74 (1977) 12, pp. 5463 5467. doi: https://doi.org/10.1073/pnas.74.12.5463.

Santiago, C. et al. (2010): "Does the polygenic profile determine the potential for becoming a world-class athlete? Insights from the sport of rowing", Scandinavian Journal of Medicine \& Science in Sports 20 (2010) 1, pp. e188-e194. doi: https://doi.org/10.1111/ j.1600-0838.2009.00943.x.

dos Santos, C. G. M. et al. (2016): "The heritable path of human physical performance: from single polymorphisms to the "next generation", Scandinavian Journal of Medicine and Science in Sports 26 (2016) 6, pp. 600-612. doi: https://doi.org/10.1111/sms.12503.

Schneider, A. J. (2016): “A Critical Review of R. L. Simon's Contribution to the Doping in Sport Literature", Journal of the Philosophy of Sport 43 (2016) 1, pp. 115-128. doi: https://doi.org/10.1080/00948705.2015.1128338.

Schneider, A. J.; Friedmann, T. (2006): Gene Doping in Sports: The Science and Ethics of Genetically Modified Athletes, Elsevier Academic Press, London 2006.

Schneider, A. J.; Rupert, J. L. (2009): “Constructing Winners: The Science and Ethics of Genetically Manipulating Athletes", Journal of the Philosophy of Sport 36 (2009) 3, pp. 182-206. doi: https://doi.org/10.1080/00948705.2009.9714756. 
Simonson, T. S. (2010): "Genetic evidence for high-altitude adaptation in Tibet", Science 329 (2010) 5987, pp. 72-75. doi: https://doi.org/10.1126/science.1189406.

Song, J. (2017): "Targeted epigenetic editing of SPDEF reduces mucus production in lung epithelial cells", American Journal of Physiology-Lung Cellular and Molecular Physiology 312 (2017) 3, pp. L334-L347. doi: https://doi.org/10.1152/ajplung.00059.2016.

Škerbić, M. M. (2016): "Etika dopinga u sportu: dvije suprostavljene perspective" ["Ethics of Doping in Sport: Two Contrasting Perspectives"], Filozofska istraživanja 36 (2016) 3 , pp. 511-530. doi: https://doi.org/10.21464/fi36307.

Tamburrini, C.; Tännsjö, T. (2005): Genetic technology and sport: ethical questions, Routledge, London.

Thakore, P. I. et al. (2016): "Editing the epigenome: technologies for programmable transcription and epigenetic modulation", Nature Methods 13 (2016) 2, pp. 127-137. doi: https://doi.org/10.1038/nmeth.3733.

Wang, T. et al. (2014): "Genetic screens in human cells using the CRISPR-Cas9 system", Science 343 (2014) 6166, pp. 80-84. doi: https://doi.org/10.1126/science.1246981.

Watson, J. D.; Crick, F. H. (1953): “The structure of DNA”, Cold Spring Harbor Symposia on Quantitative Biology 18 (1953), pp. 123-131. doi: https://doi.org/10.1101/ sqb.1953.018.01.020.

World Anti-Doping Agency, Prohibited List. January 2017. Available at: https://www. wada-ama.org/sites/default/files/resources/files/2016-09-29_-_wada_prohibited_list_ 2017_eng_final.pdf (accessed on 21 October 2018).

Yang, N.; Garton, F.; North, K. (2009): “ $\alpha$-actinin-3 and performance”, in: Collins, M. (ed.), Genetics and Sports, Karger, Basel, pp. 88-101. doi: https://doi.org/10.1159/000235698.

Zhang, Z. et al. (2012): "Angiotensin-Converting Enzyme Insertion/Deletion Polymorphism Contributes to Ischemic Stroke Risk: A Meta-Analysis of 50 Case-Control Studies", PLoS One 7 (2012) 10, p. e46495.

\section{Matea Zajc Petranović, Julija Erhardt, Matija Mato Škerbić, Nataša Jermen, Petra Korać}

\section{Genomsko preinačavanje i odabir na temelju gena povezanih sa sportsko-atletskim uspjehom - neki bio-etički problemi}

\section{Sažetak}

Projekt ljudskoga genoma završen je 2003. godine, a njegovi su rezultati otkrili dotada nepoznate detalje o našem genomu: skupinu informacija o tome kako ljudska bića izgledaju, kako djeluju, osjećaju, misle i razvijaju se. Uskoro su ostvarene i druge međunarodne suradnje poput projekta HapMap i Projekta 1000 genoma. Unatoč tomu što su primarno bili usmjereni na istraživanje varijabilnosti u ljudskoj populaciji, kao i moguće povezanosti različitih varijacija s razlicitim stanjima i bolestima, ti su projekti također znatno utjecali na razumijevanje utjecaja gena na sportski uspjeh. Usporedno su razvijene poboljšane metode genske analize i genskoga preinačavanja na temelju kojih je postalo moguće utvrditi kandidatske gene odgovorne za različite fenotipe uspješnosti u sportu te razviti protokole slične genskim terapijama za poboljšanje sportskih natjecateljskih performansi sportaša. Ovaj rad daje pregled razvoja u genetici, pregled kandidatskih gena povezanih sa sportskim natjecateljskim performansama te etičke dvojbe vezane uz preinačavanje genoma radi poboljšavanja sportskih natjecateljskih performansi.

\section{Ključne riječi}

poboljšavanje, sportska uspješnost, sekvenciranje, genomsko preinačavanje, geni kandidati, etičke dileme 


\title{
Matea Zajc Petranović, Julija Erhardt, Matija Mato Śkerbić, Nataša Jermen, Petra Korać \\ Genomische Bearbeitung und Auswahl auf der Grundlage von Genen, die mit sportlichen Leistungen in Verbindung stehen - einige bioethische Fragen
}

\begin{abstract}
Zusammenfassung
Im Jahr 2003 enthüllten die endgültigen Ergebnisse des Humangenomprojekts die Details unseres Genoms: Eine Reihe von Informationen darüber, wie Menschen aussehen, wie wir handeln, fühlen, denken und uns entwickeln. Bald darauf wurden weitere weltweite Kooperationen wie das HapMap-Projekt und das 1000-Genome-Projekt in die Tat umgesetzt. Obgleich das Hauptaugenmerk auf der Variabilität der menschlichen Population und den möglichen Verquickungen bestimmter Variationen mit verschiedenen Zuständen und Krankheiten lag, übten diese Projekte auch eine große Wirkung auf das Verständnis des genetischen Einflusses auf die sportliche Leistung aus. Parallel dazu wurden verbesserte Methoden zur Genanalyse und Genbearbeitung entwickelt. Basierend auf diesen Methoden wurde es machbar, Kandidatengene zu detektieren, die für verschiedene Leistungsphänotypen verantwortlich sind, und Protokolle zu entwickeln, die Gentherapien zur Leistungssteigerung bei Sportlern ähneln. Dieser Aufsatz behandelt Entwicklungen in der Genetik, den Überblick über Kandidatengene im Zusammenhang mit sportlicher Leistung und ethische Dilemmata bezüglich der Modifizierung des Genoms zur Steigerung der sportlichen Leistung.
\end{abstract}

\section{Schlüsselwörter}

Steigerung, sportliche Leistung, Sequenzierung, Genombearbeitung, Kandidatengene, ethische Dilemmata

\section{Matea Zajc Petranović, Julija Erhardt, Matija Mato Skerbić, Nataša Jermen, Petra Korać}

\section{La modification et la sélection du génome sur la base des gènes associés à la performance du sport athlétique - quelques problèmes bio-étiques}

\section{Résumé}

En 2003, les résultats finaux du Projet génome humain ont révélé les détails sur la structure de notre génome : un ensemble d'informations sur l'apparence physique de l'être humain, sur sa manière d'agir, de sentir, de penser, et de se développer. Peu de temps après, d'autres collaborations mondiales telles que le projet HapMap et le projet 1000 Genomes ont été menées à terme. Axés essentiellement sur la variabilité de la population humaine et sur les possibles liens de certaines variations avec différents états et maladies, ces projets ont toutefois eu un important impact sur notre manière de comprendre l'influence que les gènes exercent sur la performance sportive. En parallèle, des méthodes améliorées pour l'analyse du gène et la modification du gène ont été développées. Il est devenu possible sur la base de ces méthodes de détecter les gènes candidats responsables des différents phénotypes associés à la performance et de développer des protocoles similaires aux thérapies géniques afin d'améliorer les performances chez les athlètes. Cet article passe en revue les développements en génétique, donne un aperçu général des gènes candidats associés à la performance athlétique et des dilemmes éthiques liés à la modification du génome dans le but d'améliorer la performance sportive.

\section{Mots-clés}

amélioration, performance sportive, séquençage, modification du génome, gènes candidats, dilemmes éthiques 